\title{
ECONOMIC CHANGE AND TRANSITION OF MALAY SOCIETY IN MALAYA IN LATE NINETEENTH AND EARLY TWENTIETH CENTURIES
}

\author{
A Rahman Tang Abdullah
}

\begin{abstract}
This article discusses economic change and its relevance to the consciousness and transition in Malay society during British colonial rule in Malaya. The period of this study is the late nineteenth and early twentieth centuries. In this context, the fundamental concept of economic change is applied to the change from self-sufficiency or subsistence to conmercialism. The word 'consciousness' here is refer to the extent to which Malay society in general hegan to realize and was prepared to adapt to the nea phenomena of economic changes. The word 'transition' here refers to the slow pace in the process of economic change in their involvement, practice and types of economic activities wolnch manifested a distinction between traditional and modern orientations. The subject of discussion is composed of the aspects of traditional economy in the nineteenth century and general features in the process of transition in the Malay society such as land, labour utilization, pudi cultivation, agricultural credit facilities and contmercialism.
\end{abstract}

\section{Introduction}

Generally, it can be observed that the Malay economy in Malaya during the British colonial period has not yet been exclusively discussed in a substantive manner by historians and sociologist. It can be observed that the existing writings concerning the Malay society in Malaya during the British colonial period have been extensively concentrating 
on political and social aspects. This dimension is clearly manifested as it can be found in the historical and sociological perspectives. Meanwhile, even though this particular subject has been directly or indirectly discussed by many historians and sociologists, it can also be identified that they have given less attention to the economic aspect of the Malay society in Malaya during this period. In other words, until now, the economic aspect of the Malays during this period has not been exclusively and thoroughly explored by any scholar. In fact, even from the economic perspective, the existing writings only focus on the expansion of capitalist economy or large scale economic activities which were associated with commercial orientation and export economy such as tin mining, commercial plantation and trade. Most of the practices and institutions connected to those economic sectors were virtually dominated by the Europeans especially the British and other immigrant communities especially the Chinese. This typical phenomenon can be seen in the writings of John G. Butcher, Chai Hon Chan and James C. Jackson.

It is understandable that the economic aspect of the Malay society during the colonial period is not treated as a primary subject by the British colonial administration in Malaya. This is based on the fact that most historical sources derived from the British colonial record indicate that the colonial authorities gave prime concern to economic activities which were associated with export economy. In fact, based on the reality of the nineteenth century, economic imperialism actually preceded political imperialism or colonial expansion. It is evident that the British authority as a whole was more concerned with the economic criteria in formulating their policy towards the Malay states. Since economic dominance had become their imperial aspiration, the export economy sectors were largely dominated by the European and Chinese immigrant communities. Thus, in this historical context, based on economic perspective, it is understandable that the British authorities had given the Malays less attention compared to those Europeans and Chinese. Thus, this article examines the aspect of economic change and its relevance to the consciousness and transition in the Malay society during British colonial rule in Malaya.

\section{Traditional Malay Economy in the Nineteenth Century}

Generally, it can be said that the period between the mid and late nineteenth century is regarded as the eve of colonial period in Malaya. In a more definite context, the pre-colonial period is referred to the duration before 1874 for the Western Malay states such as Perak, Selangor and Negeri Sembilan, the years before 1889 for Pahang and before 1909 
for the Northern Malay States such as Kedah, Perlis, Kelantan and Terengganu. Even more in a literal context, the pre-colonial period is still applied to Johor in the years before 1910-14. The years before 1874 are only applied as colonial period to the Straits Settlements of Penang, Singapore and Malacca. This is based on the general consensus among many historians who unanimously adopt the colonial period in Malaya to the year when the first British Resident, Adviser or General-Adviser was appointed in the Malay states.'

Accordingly, based on this context, the historical status-quo in the second half of the nineteenth century is used because the traditional practice and orientation can still be traced in the economic aspect of the Malays during this period. Moreover, the majority of the Malays in this period were actually living in the rural areas. Most of them were still associated with their traditional occupation as peasants and fishermen. Most of the Malay peasants were involved in padi cultivation especially in Kedah, Perlis, North Perak and Kelantan. They were also involved in other small scale economic activities such as animal husbandry, fruit and vegetable cultivation as well as other supplementary occupations such as hunting, mining and collecting jungle products such as dammar, rattan and bamboo. " Those activities manifested the phenomena that their daily life was closely associated with land as they were peasant communities in the villages.

Nevertheless, in the Malay traditional society, the concept and practice of economic domination was applied to human resources as labourers and economic products and not the control over the piece of land. This particular fact manifests the fundamental characteristic which is totally different from the modern concept of land ownership. The political hegemony and economic exploitation by the Malay ruling class over their subjects 'rakyat' was demonstrated in the form of corvé or forced labour (also commonly known as 'kerah' and the institution of slavery. In the Malay tradition, there were three types of slaves-, royal slaves, debt slaves and permanent slaves. Another type of labour in the Malay tradition was derived from voluntarily collective labour (also known as 'gotong-royong). ${ }^{3}$

Basically, a piece of empty land in a specific area or location was not a property and had no economic value if it was not inhabited and did not generate any form of revenue. It is necessary to note here that the most important source of revenue was derived from sustainable agricultural activities. In this context, the significance of land was associated with permanent settlements which were primarily related to farming activities. Other supplementary revenues derived from jungle products and mining were less important unless those two sources of revenues were available in a large deposit and became the commercial 
products due to high demand such as gutta percha in the 1840s in Johor and tin in Perak and Selangor. Another possibility for the land to become valuable is if it possessed gold. This can be seen in the case of the inland area of Raub in Pahang. Otherwise, without agricultural activities in a particular land area, it was regarded as merely jungle land. Initially, this jungle land had no value even if it possessed abundant products unless it was then opened up as villages. The land area which was utilised for agriculture and then generated revenue was known as 'living land' (tanah hidup). In contrast, if a particular land area was abandoned by its settlers until it became neglected (untamed), it was perceived as having no value and was known as 'dead land' (tanah mati). ${ }^{4}$ This concept was not only practised in the Malay tradition but it was also adopted by the British administration in Malacca in the 1860s.

In other words, even large areas of land had no political and economic value if it was not occupied by anybody as a settlement. The significant interconnection in both political and economic perspectives can be seen in the case of Johor. Before the 1840s, Johor was not significant because it was sparsely populated. According to John Crawford, Resident-General of Singapore, in the 1820s, the whole territory in the southern coast of Johor, from Ramunia in the East and Kukub in the West were merely jungles without inhabitants. It was estimated by Begbie that the number of its inhabitants was estinated not more than 1000 ?

Johor became economically valuable only in the 1840s when gutta percha was discovered in abundance in its jungle which began to generate revenues for the Temenggung as the de facto ruling authority in the territory. Temenggung Ibrahim ordered his followers who were originally the sea people (Orang Laut) to collect the plant which then became the commercial product for export in the world market because it was discovered as the most suitable substance to be used for protecting deep-sea cable and for surgical and chemical apparatus. It was estimated that the revenue derived from gutta percha at the end of the $1840 \mathrm{~s}$ was between $\$ 150,000$ to $\$ 200,000$ per annum. ${ }^{8}$ Simultaneously, the economic significance of Johor was further enhanced by the advent of Chinese immigrants who began to open up the land for commercial plantation of pepper and gambier. This economic development then became the chief factor of Johor's political significance in the mid nineteenth century."

Generally, most of the modern practices related to the modern concept of land ownership were not applicable in the traditional Malay society. In the traditional context, the concept of private land ownership was adopted as an implicit rather than explicit practice. Here, the implicit concept of private land ownership refers to the situation in which a particular land in a specific location was acknowledged as the land 
belonging to an individual or a family who lived in the area. Normally, the individual settlement in a particular area was established as the Malays were not nomadic and they chose the area for their permanent agricultural settlement. This led to the transformation from jungle areas to a village. Their ownership to the land remained as long as they still lived in the area unless they were expelled from the village by the headman or the chief or they had to abandon the area because of disturbances and war. In a more practical circumstance, losing the right to live in a particular area was due to the land being abandoned because they had to move to other locations. They would have the opportunities and rights to the land if they came back to resettle there and it was still unoccupied by other settlers. Hence, if this particular land was then occupied by other families, the new settlers would have the right to live there. ${ }^{10}$ This traditional practices and orientations were sanctioned by the Portuguese and Dutch as well as the British colonial authorities in Malacca in the nineteenth century."

Moreover, during the same period, the Malays were inclined to establish permanent settlements on a particular land in the village and there was virtually no possibility for them to abandon the settlement. Generally, the tendency for the Malays to permanently settle down in a particular area was related to two factors. Firstly, the particular land in a particular location had economic potential for sustainable agriculture. Most of the agricultural activities were directly associated with food products especially padi, tapioca, coconut, sugar cane, bananas and betel-nut, and fruits as well as animal husbandry and fishing to fulfil their basic needs in accordance with economic subsistence. In this situation, the main location for settlements could be found at the areas in adjacent to the rivers and sea coast. However, the more favourable areas were the river valleys which provided sources for drinking water and irrigation for agriculture. In principle, rivers deposited fertile silt on adjoining fields, provided water for crops, offered fish supply and served as a venues for inter-village communication and trade.

It is generally discovered that the village areas where the land were located near the rivers were more fertile than the land far from the rivers. Rivers deposited fertile soil when they overflowed their banks. The result of this process provided natural sources of fertility for agricultural activities before the invention of chemical fertilisers. The natural situation was further developed through constructing and maintaining irrigation work. In contrast, the land areas near the jungles and hills were virtually dependent on the rain water and the natural fertilisers derived from animal droppings. Eventually, the amount of natural fertilisers would reduce and the output became less after several cultivation seasons. This is due to the absence of soil replenishment 
on the land away from the rivers. This was the reason which did not contribute to the emergence of vast settlements in the areas far from the rivers. ${ }^{12}$ This is the main reason for most prominent settlements and villages in the Malay Peninsula to be found near the rivers. The same phenomenon can also be noticed in Malacca in the nineteenth century. ${ }^{13}$

Secondly, a settlement was prone to be in areas where natural and constructed irrigation was available. In addition to rivers, other sources of water were streams, canals, ditches and dikes. Having the sourced of water in the settlement was fundamental for the establishment of padi cultivation which produced rice, a staple diet for the Malays. ${ }^{14}$ Accordingly, vast permanent settlement areas were founded in the location suitable for padi cultivation in the Northern and Eastern states of Malaya. Another prominent settlement is the Minangkabau Malays in Negeri Sembilan where there is evidence of their ability in constructing irrigation facilities for padi fields. In fact, their inventiveness in this respect can be traced from the historical origins and development of Minangkabau settlements in Naning, Melaka in the sixteenth and seventeenth centuries. ${ }^{15}$

In addition to agriculture, there were also business activities in the traditional Malay society. However, it was quite limited because there would normally be one shop in a village. Here, money economy was not extensive among the rakyat because most of them either have little amount or did not possess money at all. Thus, most of the business transactions were conducted through the barter system. The business activities were normally related to the transactions of acquiring the products which were not produced by them in the village such as cloth, salt and tobacco." The practice of money economy was more extensive among the Malay ruling class who were normally engaged in trade with the immigrant communities of A rabs, Indian Muslims, Europeans and Chinese. In fact, they also have virtual control over the rakyat and the Chinese labourers who began to migrate to Malaya in the nineteenth century.

Here, the main mechanism of economic control was in the form of tax imposed by the Malay chiefs on the people. The main source of tax was revenue tax which was known as Cukai Raja (Royal tax). The rate was normally 10 per cent and was imposed on agricultural and mining products. This tax was normally paid by using the products themselves especially padi and tin. In fact, land tax in accord ance with the modern concept such as annual tax and land concession for a particular lease period was not yet fully imposed by the British authorities in Melaka unsil the third quarter of the nineteenth century. The provision of 10 per cent of revenue tax stipulated as royal tax in accordance with the Malay tradition was sanctioned by the British administration and was 
imposed on the Malays in Melaka in the second half of the nineteenth century. ${ }^{17}$ Furthermore, this concept of taxation was still practised in Muar, Johor in the 1870 s. $^{18}$

The only tax paid in money was in the form of export duties on tin and other export goods, import duties on liquor, opium and rice as well as other goods in the trading transaction. ${ }^{19}$ The use of money as tax payment was exclusively practised in revenue farm sectors when the Malay rulers and chiefs authorised the deal with the Chinese. This can be found in the concessions of padi cultivation in Kedah, pepper and gambier plantations in Johor and tin mining in Perak and Selangor. Any particular concession covered a certain period from one to ten years. ${ }^{20}$ On the other hand, the rakyat had less opportunity to engage in money economy since their involvement in money transaction was very limited. The most possible channel for them to obtain money for their work was derived from tin mining. It is quite difficult for them to obtain money through padi cultivation, even in the harvesting season because most of them worked for the padi farmers who also expected to derive the money from the sale of their crops.

Thus, generally, it can be construed that the success and the failure of the Malays in general to adapt themselves to the economic changes in the nineteenth century were dependent on the Malay ruling class who were prepared to adapt themselves to the modern economic orientation. This is because they had access to money derived from tax and commercial activities. So, they were able to have access to both governmental and commercial financial sources as money was the fundamental requirement to become involved in money economy. In principle, a certain proportion of those financial apparatus were converted to capital in commercial activities which generated profits. Apparently, they were supposed to initiate and promote the process of economic transition among the rakyat. This could have been achieved in a constructive manner by giving the opportunity for the rakyat to be accustomed to economic transition at elementary stage. This action could have been the initial stage for the Malays as a whole to adapt to the new orientation and practice.

Nevertheless, the Malays ruling class were more inclined to form ventures with the immigrant communities who had been involved and accustomed to money economic orientation rather than to initiate economic transformation among the rakyat. This trend can be seen in two cases. Firstly, in Kedah, concessions for padi cultivation were granted to the Chinese by Sultan Abdul Hamid Halim Shah in the late nineteenth century. ${ }^{21}$ Secondly, in Johor, there were several joint ventures between the Temenggung authorities and the Sayyids and the Chinese in commercial plantations and mining concessions in the 
second half of the nineteenth century..$^{22}$ These circumstances indicated that the Malay rakyat were not given elementary opportunities to become involved in commercial activities.

This situation also retarded the pace of the rakyat to adapt with the new economic orientation in a larger extent than just the basic circumstances. The basic circumstances in economic transition among the Malays were referred to their limited opportunities to gain petty labour wages on temporary basis. This petty income was only sufficient for them to purchase the daily needs which were not produced by them. This situation did not provide opportunities for them to generate surplus which could be used as initials or even tiny capital investments for petty business activities. The opportunities for them to become petty shopkeepers or peddlers were very limited and became elusive. This is because the only source of capital was derived from the Malay chiefs who were not willing to provide initial capital investment to the lower class Malays who wished to become involved in commercial activities.

On one hand, it is understandable that the Malay chiefs did not prefer to establish joint ventures with the Malay rakyat who were regarded as inferior in economic achievement and lack the experience of handling money in accordance with the practice of mercantilism which was necessary in the managing business activities. This is because commercialism is related to the practices and spirit of commerce or profit-making. Even in the case of the Malays who were industrious, they only managed to become petty traders in the local market in small towns or the areas nearby the royal residency. This phenomenon can be seen in the case of the women in Terengganu in the nineteenth century. They were not able to make any major impact on the Malays as a whole because their activities remained in small scale and were not able to expand due to the lack of further increase in capital. Consequently, the business sectors continued to be dominated by the immigrants and the Malay upper classes who had advantages because of their access to money economy. This showed that there was virtually no vertical economic mobilization in the traditional Malay society. It meant that the Malay rakyat were not able to improve and change their economic status from the poor to a better situation as middle class citizens in modern economic term. On the other hand, the Malay upper classes continued to enjoy their privilege in the society because they were able to further enhance their economic condition by collaborating with the immigrant communities.

\section{Economic Transition and Change}

It is unanimously agreed by historians that the years between 1850 and 1941 are regarded as the period of transition from traditional 
to modern orientation in the economic aspects of the Malay society in Malaya. This transitional process was the cause and effect of the economic change which was shaped in accordance with the practice and orientation in European capitalism as a result of the advent of British imperialism to Malaya. The word 'transition' here means that the extent of the changes in the economic aspects of the Malays as a whole was merely a gradual rather than rapid process. In this context, the economic changes from traditional to modern manifestations were perceived as less eminent than the manifestation reflected in the case of the immigrant communities of Chinese, Arabs and Indians. In fact, it can be observed that the traditional economic features still prevailed in the Malays in the late nineteenth twentieth century as it has been discussed in the preceding section. This is because the reaction from the Malays to the changing economic pattern and orientation in capitalism and commercialism was relatively slow compared to those immigrant communities.

In this respect, it could be construed that the fundamental cause for the slow pace of the Malays to adapt themselves to the new economic practice and environment was due to the basic contradiction between the traditional and modern economies per se. In principle, the prevalence of traditional economic practice and orientation among the Malays during the nineteenth century should be regarded as the main constraints for the Malays to achieve economic progress and dynamism. In fact, there are many aspects which distinguish the practice and orientation between the traditional and modern economy which are associated with the advent of colonial authorities. Some of those differences are fundamental in their nature.

In order to observe the economic transition of the Malays as a whole, it is sensible to examine the aspect of change from traditional to modern economy among the majority of the Malays in the late nineteenth and early twentieth centuries. This period was regarded as the formative period of economic change considering the circumstances that the Malays began to be exposed to the modern economic orientation. It can be said that the Malays including the rakyat also began to depart from traditional practice and orientation. Even though their numbers were still small compared to the immigrant communities the rakyat began to adapt themselves to new situations by exploring in any economic opportunities which provided the prospect for them to achieve vertical economic mobilization to a middle class level. This phenomenon can be observed by examining the historical development of the Malays in agriculture and its relevant aspects especially land, business and new occupation. 
In historical context, the basic changing orientation in Malay agricultural orientation was the departure from subsistence or selfsufficiency to capitalism. It is evident that the change in orientation which is based on the principle of capitalism can be seen in business and trade. In fact, the Malays had been involved in those economic sectors even during the pre-colonial period. Nevertheless, those sectors were dominated by the Malay upper classes, not the rakyat. ${ }^{24}$ Thus, it is supposed that under the new situation, the upper class Malays continued to enjoy the advantages in economic domination of the Malays by associating themselves with the immigrant communities as well as collaborating with the colonial authorities. This phenomenon reflects the circumstances that the process of transition was more associated with the ruling class rather than the rakyat. Consequently, the rakyat still remained as peasants and fishermen until the first half of the twentieth century. It is even hard to imagine that the rakyat would have the opportunity to become petty shopkeepers or peddlers due to the lack of financial support especially credit facilities which were normally available to the capitalists and mercantile community. In fact, in the late nineteenth century, it is hard to imagine that any Malay peasant could possess even $\$ 10 .{ }^{25}$

Thus, it is also necessary for the Malay peasants to be exposed to money economy in an explicit manner. They began to have access to financial sources channelled by the government to the agricultural sectors. Theoretically, the breakthrough of the transition is visible among the Malay peasants in the villages in the early twentieth century. The Malays began to be exposed to money economy through agricultural activities which could generate money to the peasants although it was still at an elementary stage. This can be seen in padi cultivation itself, as well as rubber and coconut plantations whereby the rakyat became smallholders. In principle, the financial income generated from these activities could be saved as surplus or extra savings. Thus, the surplus was to be used to break new grounds for small commercial activities. Hence, a number of the rakyat became peddlers, shopkeepers, brokers and other petty entrepreneurs. They also began to be exposed to credit facilities and modern institutions which were designed to accommodate the agricultural sector in rural areas.

\section{Labour Utilisation}

In order to improve the economic condition of the Malay peasants, there must be a starting point for the Malays to convert their nonmonetary resource to monetary returns. The basic resource possessed 
by the peasants was labour which can be translated into human capital. Indeed, this became the conventional means for the lower class Malays to explore the opportunity in the process of transition which was derived from the change in labour utilization. Traditionally, labour in economic activities was derived from personal or family workforce. It mostly concerned agricultural activities due to the nature of peasantry. Nevertheless, there was also forced labour whereby they were forced to render services to the chiefs. This certainly retarded their personal economic achievement as they were also compelled to contribute their labour for 'kerah' or corve labour. There was the possibility for them to succumb under debt slavery due to their inability to pay their debts to the Malay chiefs. Slaves did not receive wages for their work except for basic daily food and clothing from their lords. Eventually, slavery and corvé labour were abolished by the British. ${ }^{26}$

Consequently, this measure gave an opportunity for the peasants to freely utilize their personal workforce for their own agricultural productivities or to serve as wage labour. Nevertheless, it was discovered that the Malays in the 1880s were not in favour of being employed as permanent waged labour in plantations and mining sectors. They were keener on working as temporary labourers especially for clearing the jungle for plantation areas. ${ }^{27}$ The Malays were also involved in cutting down trees and collecting jungle substances for the construction of temporary shelters in the mining areas. ${ }^{28}$ Their reluctance to commit themselves to waged labour was understandable because they were not prepared to leave their families in order to live in the plantation or mining areas where they would be isolated from their villages.

Certainly, there are some reservations on the Malay perceptions and responses to the changing orientation of labour utilization in commercial orientation. Their reluctance to become involved in the plantation and mining sectors gave the space for the immigrant labourers to penetrate into those sectors. However, there were also other promising prospects for the Malays to utilize their labour in a more profitable manner in order to pursue their economic means. In those days, land was plenty. Under the new order, land now became valuable because it can be purchased and sold to any party especially the Europeans and other immigrant mercantile communities. The initial capital investment for opening up land can be observed in the payment of labour force. This certainly provided the practical means for the Malays to exchange their labour into money as they received wages for opening up the land for plantation areas. Furthermore, they were now able to exploit their labour for opening up the jungle land for their own agricultural activities. 


\section{The Change in Land Ownership}

It is evident that the most advantageous way for the Malays to pursue their personal economic gain in the new order in those days was the utilization of their personal workforce to opening up jungle land for agricultural purposes. This opportunity emerged due to the new concept of land ownership introduced by the colonial authorities. This referred to the concept of private land ownership to individuals and land can be inherited within the family and can be disposed to other individuals or institutions through sale and purchase. Based on the new land laws of the states in Malaya in the late nineteenth century, it was a standard practice that that land ownership can be legally acquired through the permission from the state government to open up the jungle land.$^{29}$

In the 1870s, it could be construed that the Malays began to perceive land as a commodity to be possessed as private property but not yet to the full extent of land transaction in which the ownership of land can be transferred to other parties according to the value of land per se. This is because the Malay tradition only appreciated the land based on continuous occupation and agricultural exploitation. The value of land was based on the products and revenue generated from the land rather than the land itself. Consequently, it was significant for the rakyat to acquire land as their property for living and small scale agricultural activities since these types of land utilization was not different from the traditional utilization among the rakyat.

There was no tendency yet to utilize land for commercial purposes in an extensive manner through injecting investment for developing the land. In those days, the main forms of capital investment on land were the concept of revenue farm or concession which was practised by the Europeans and immigrant Chinese. ${ }^{30}$ It was quite elusive for the Malays to accept the practice similar to the Kangchu System in Johor that they had to pay rent or concession for 10 years if they open up the jungle land. This is because those jungle lands were regarded as dead land and the Malays appear to apply rent only on living land.

Moreover, they were also not yet accustomed to pay land tax, premium and quit rent because traditionally, there was no land tax imposed on land belonging to any individual and institution. This is because the Malay tradition acknowledged land based utilization for agricultural purposes rather than possession in the modern context. The permanent ownership of land was irrelevant because if it were left uninhabited and unutilized by an individual, it became dead land and not belonging to any individual anymore. Moreover, the practice of the purchase of sale of land among the Malay rakyat was very minimal because in those days, jungle land was plenty and easily available to 
be opened up with the permission from the state authority. Land tax was not yet applicable as long as it was not yet surveyed. Even in the second half of the nineteenth century, most of the surveyed land in Johor were to accommodate the opening up of the Chinese Kangchu areas. ${ }^{31}$

Since the issue of land tax was not relevant to the opening up of the land in Johor by the Malays before 1910, they still perceived that jungle land was freely available and could be explored without any charge. This led to the opening up of the new villages by the Javanese who migrated to Johor particularly the Muar district in the 1870s. Nevertheless, it did not mean that the concept of private land ownership was applicable to those occupants in those villages. The land was only regarded as merely 'Tanah Kurnia' or conferred land. ${ }^{32}$ Here, the private land ownership was not applicable because the land was still subject to the procedure under the Department of Land and Survey. This procedure involved the process of registration and survey for the purposes of the imposition of land tax.$^{33}$ Land tax only became fully practised in the second decade of the twentieth century when the first land Enactment was ratified in the state in 1910.

Initially, most of the Malays who accepted the concept of private ownership in accordance with the Western concept and orientation were the immigrants from Java, Sumatra and Borneo. The Malays in Malaya as a whole were subjected to this modern orientation when the Land Laws were codified and gazetted. The most crucial Land Law which had a major impact on the Malays as a whole was the Malay Customary Law of Negeri Sembilan of 1907 . These new concepts and orientations of private land ownership were then further expanded and exclusively enforced with the ratification of the Malay Reserved Land Enactment of 1913 in the Federated Malay States. The exclusive provisions regarding the land ownership by the Malays in the 1913 Land Law was then applied as the standard form including the amended Johor Land Law of 1936.

Theoretically, it could be construed that private land ownership was the most acceptable concept for the Malays as it can be acquired through the opening up of the Jungle land. The opening up of the land was normally carried out as 'gotong-royong' or collective activity among them and did not incur wage expenses. Nevertheless, the Malays were also subject to restriction in this activity because they perceived that land tax as a burden if they acquire large areas of land. For instance, the initial charges for the land tax in Johor were 30 cents for the first 2,000 acres and $\$ 5$ for the subsequent acre above 2,000 ${ }^{34}$ However, the farmers were eventually charged $\$ 5$ per acre several years after. Consequently, the Malays tended to be smallholders and each individual only possessed the land of not more than two acres. ${ }^{35}$ 
It was the noticeable that the main problem faced by the Malays was paying the tax for the land after its opening up and the process of land survey. The amount of outstanding tax to the states authorities of the Federated Malay States continued to accumulate. The land subjected to outstanding land tax was faced with the possibility of to be seized or foreclosure by the state government. This problem arose because they gave less priority to pay land tax. It is understandable that they had to spend their money for other purposes especially for purchasing food, clothes and other consumer goods. However, due to their complacency in paying land tax once in a year, it led to the delay of the payment and the amount of outstanding land tax continued to increase. Eventually, it led to the land alienation among the Malays and this problem was specifically highlighted in the Federal Council in $1933 .^{3 \circ}$

\section{Land and Padi Cultivation}

Land is certainly associated with agricultural activities. The main aspect which manifested the transition in agricultural activity of the Malays was padi cultivation. The only state which revealed the credits for the Malays to produce surplus in padi cultivation during the pre-colonial period was Kedah. ${ }^{37}$ However, to the Malays, the padi production was to fulfil the requirement for the family and the village community. Thus, the tendency to produce surplus did not become a priority although until the first half of the nineteenth century, there were also exports of padi from Terengganu and Kelantan to her neighbouring territories. ${ }^{38}$ Consequently, the padi cultivation remained as subsistence in the economic activities of the Malays in the nineteenth and twentieth centuries. Even in the case of Kedah in the late nineteenth and early twentieth centuries, the expansion of padi cultivation as commercial products was much more associated with the Chinese rather than the Malays. $^{34}$

Here, the change from subsistence to commercial orientation referred to large scale production in order to achieve the ends to produce surplus. It is noticeable that the pace of the Malays to transform their scale of production to a larger one in order to fulfil commercial requirement were slower compared to the Chinese. This is because there was no major change in the practice and orientation in order to expand the production. Most of them still remained as smallholders and their labour resources were limited to family members. The expansion of scale of production needed the development in technological improvement and the increase of land areas of padi farms 'sawah'. Those aspects of expansion could only be derived from capital investment in the padi cultivation itself. In the case of Kedah, the resources of capital investment 
in padi cultivation in the late nineteenth century was mainly provided by the Chinese merchants who obtained the concessions in the form of revenue farms from Sultan Abdul Hamid Halim Shah. ${ }^{40}$

In addition to capital investment, large-scale padi farms required good irrigation systems and large maintenance cost throughout the cultivation season. The cost of construction and maintenance of modern irrigation systems and dams could only be derived from state financial assistance. Normally, the private investors were not interested in financing those schemes because padi cultivation was less profitable compared to other commercial plantations especially coffee and rubber. In fact, the colonial authorities did not perceive financing irrigation schemes and dams as main priorities although the Malays were basically encouraged to be involved in the padi cultivation. This is because the British tended to acquire rice supplies imported from Siam and Burma because the price of imported rice was cheaper than the cost of rice production in Malaya as a whole. ${ }^{41}$

\section{Agricultural Credit Facilities}

Certainly, the dependence of agricultural activities on financial matters was so eminent in the transformation from self-sufficient to commercial orientation. In this context, the lack of financial assistance for initial capital expenditure and operational cost was certainly the fundamental restricting factor to increase the scale of production beyond selfsufficiency. The most conventional financial assistance is subsidy and agricultural credit facilities. For the peasants, they had to depend on governmental fund, or the capital injection from the Malay chiefs and immigrant mercantile communities who had long been accustomed to money economy. Under this circumstance, it is understandable that they highly expected governmental funding especially in padi cultivation. This is because private investors were reluctant to inject capital investment on padi cultivation scheme since this activity was commonly exposed to the prospect of failure. In fact, padi cultivation was more risky compared to other agricultural activities because of its nature of highly depending on excessive irrigation and continuous water supplies throughout the process of cultivation. Even in the harvest season, it was exposed to flood which could destroy the padi. ${ }^{42}$

In the late nineteenth and early twentieth centuries, there were several initiatives from the state governments to provide small credit schemes only for agricultural purposes to the peasants. In 1884, the Government of Selangor set up a credit scheme for funding agricultural activities in the state. According to the scheme, all district officers were given the grant of $\$ 1,000$ per annum for agricultural loan in Selangor. 
Then in 1895, another scheme was introduced in the Federated Malay States in which the residents were authorized to grant loan to the farmers. According to this scheme, the Residents of Perak and Selangor had the authority to endorse the agricultural loan of not more than $\$ 1,000$ for each selected farmer. However, the maximum amount of the credit scheme was only $\$ 5,000$ per annum. In Negeri Sembilan, the similar scheme only prescribed the credit scheme of $\$ 200$ and the maximum amount was $\$ 1,000$ per annum. ${ }^{43}$

It is evident that those agricultural credit schemes were still far from adequate to accommodate the farmers because the amount was very small and thus not all of them were able to enjoy the credit facilities. Moreover, it is not clear whether the credit scheme was exclusively allocated for the Malay farmers. In the early twentieth century, there was an increase in the number of farmers especially of those who were involved in the opening up of land for padi cultivation in Krian after the irrigation system was constructed in the district in $1895 .{ }^{44}$ Most of them were the Malays who migrated to Malaya from Java, Sumatera and Borneo. Thus, in 1907, E. W. Birch, the Resident of Perak, had forwarded the application to the High Commissioner for the establishment of an agricultural bank with the initial fund of $\$ 25,000$. There was also a suggestion that a similar scheme was to be extended to other states. ${ }^{45}$

Thus, in 1908, an agricultural fund was established in the Federated Malay States. The purpose of the fund was to provide loan for agricultural purposes which included the construction of the drainage system for irrigation, purchase of buffaloes and other farming tools, the building of houses on the farm land and the development of the land in general. The loan could also be granted for the purpose of recovering the agricultural land which had been put on mortgage to the money lenders. The interest rate was 4-6 per cent. However, it was discovered that the establishment of the fund was not so effective in giving benefits and solving the problems faced by the farmers. According to the Perak Treasurer, only half or less than half of the farmers applied for the loan. This is because they were discouraged by the loan application procedures and the amount which could be approved by the District Officer was only $\$ 100$. This amount was regarded as too low for the value of the mortgage. In principle, the amount of the loan that could be granted was based on 50 per cent of the value of the mortgage which should be agricultural land. However, the amount of the loan to be approved was normally based on 30 per cent of the value of the mortgage. Despite this restrictive terms and conditions, most of those borrowers were late in repaying their principal loan as well as loan interest. ${ }^{\text {to }}$

Then in 1911, another agricultural fund was established in the Federated Malay States. Although all the provisions relating to the 
purposes of the fund were quite similar with the 1908 fund, it also contained additional provisions relating to the mortgage. According to the rules, the District Officer was given the authority to endorse the loans from this fund for agricultural purposes and the loan could not be given to an individual who was not a farmer. The amount of the loan could not exceed 50 per cent of the sale value of the mortgage which could be the designated farm land or any land or property in the town area and not the abandoned farm land. Basically, the amount of the loan was $\$ 250$ for a farmer but it could be extended to $\$ 500$ for more than one loan. For a farmer who wished to acquire the loan for more than $\$ 1,000$, it should be approved by the Chief Secretary of the Federated Malay States. The duration of the loan was not more than 3 years and the montlly interest rate was 1-2 per cent. If there were outstanding payments of loan instalments due to the decline or damage to the agricultural products or project, the extension of the duration for the loan could be granted based on the Residents' discretion. ${ }^{47}$

However, it can be observed that the existence of the schemes and fund did not present a positive reflection on the farmers. This is because most of them succumbed into more problematic financial difficulties. The most identical problem was loan repayment. The farmers borrowed from the moneylenders especially Chettiars who imposed high interest rate on the loan. The loans were easily available from the Chettiars who were willing to give a larger amount than the loan from the agricultural fund. This phenomenon led to land foreclosures by the Chettiars because most of the farmers had put their land as mortgages on the loan. Consequently, due to the failure to repay the debts, some of the land was seized by the Chettiars. Then, in order to recover their money, the Chettiars would sell the land to any buyer who would probably be among the non-Malays. This led to land alienation from the Malays. Consequently, there was a decrease of land owned by the Malays. This led to the action taken by the Federated Malay States authority which was to limit land alienation among the Malays by the promulgation of the Malay Reserved Land Enactment of 1913.48

Meanwhile, the government of the Federated Malay States was committed to grant the agricultural loans to the farmers in order to encourage them to cultivate padi as food commodity. In 1917, the total agricultural loan granted by the Federated Malay States was $\$ 119,356$. It was estimated that 90 per cent of the total amount $(\$ 107,421)$ was allocated for padi cultivation. Other agricultural loan was granted for the plantation of coconut and animal husbandry. Even despite the increase of the loan grant made available to the peasants, they continued to borrow from the Chettiars even though the interest rate was excessive. 
This is due to the problem that most of their land did not have value to be mortgaged for government loans. ${ }^{49}$

\section{The Malays and Commercialism}

It is obvious that the existence of credit facilities in agricultural activities especially padi cultivation was closely related to money economy and commercial orientation. However, the commercial orientation in agricultural activities was not referred to padi as the Malay's staple diet but the cultivation was to fulfil the world market demand. It is evident that padi cultivation in Malaya was not intended to become the sector to produce world market demand. It was merely intended to increase the padi production in order to reduce the dependence on the rice imported from other countries. Thus, under this circumstance, it is reasonable to contemplate that the Malays were required to become involved in the plantation of coconut, tapioca, tobacco, pepper, gambier, coffee and rubber even though most of the Malays were smallholders due to the small scale of their activities. In the early days of colonial authorities, there was no vast involvement of the Malays in commercial sectors.

The only significant expression of their participation in commercial activities was related to rubber cultivation as the Malays began to realize that rubber plantation was more profitable than padi cultivation in the beginning of the twentieth century. In fact, the prospect of rubber to become the main mechanism for the Malays to generate wealth was raised in the Utusan Melayu in 1908. It was predicted that the Malays would become smallholders as they were able to acquire the land through private ownership..$^{50}$ Nevertheless, the colonial authorities imposed constraints on the Malays by exercising discrimination on them in order to discourage them from become involved as smallholders. The British did not grant private ownership to the smallholders in rubber plantation in order to preserve the interests of the European capitalist investors. ${ }^{51}$ In fact, it was officially stated that there were less efforts to be channelled for padi cultivation because it received rivalry from other plantation especially rubber which was perceived as more profitable than the former. ${ }^{52}$

This action certainly retarded the process of transformation of the Malay peasants to commercial economic orientation. The progress in economic achievement of the Malays as a whole was highly dependent on their pace to adapt themselves and to become involved in commercial economic activities even if they were exposed to high risks. The main feature in commercial orientation is money as capital investment for business and agricultural sectors. In agricultural context, the initial practice of commercialism can be seen in the aspect of farm revenue 
which involved mortgages and concessions at the beginning of the operation.

However, the majority of the Malays were not accustomed to these concepts and practices in commercialism. From the lower class perspective, it is evident that the Malay peasants did not have the advantages to have access to financial facilities for the purpose of initial capital investment compared to the Malay aristocrats. The only viable source of initial capital in those days was derived from the government credit scheme. In fact, as it has been mentioned before that the Malay aristocrats continued to establish joint ventures with the immigrant Chinese in business and plantation concessions after the advent of the colonial administration. The Malay peasants were not only faced with fundamental economic difficulties but also with the question of religious norms. In the early twentieth century, the most outstanding religious difference of opinion, which was applied to the government loans and cooperative bodies, was the issue of interest known as Riba ${ }^{\prime} .^{53}$

Unfortunately, the Malays who were widely implicated in the prohibition of Riba' in Islam was the Malay peasants and petty shopkeepers and traders who were borrowing from the government and cooperative bodies. The issue of Riba' was firstly related to establishment of rural cooperative bodies as the means to resolve debt problems among the Malays especially the peasants. It was referred to the payment and income associated with interest derived from the loans from cooperative bodies. In fact, even in the case of savings, the Malays in general were not encouraged to save their money in the bank institutions. This is based on the assumption that it would not only generate Riba' or bank interest but also give the loan to the bank to generate interest for the bank. Even though there were counter arguments on this matter, it is difficult for the Malays to accept the view that the interest imposed on or derived from the loan was not Riba ${ }^{\prime}$ and was Haram or not permissible in Islam. ${ }^{54}$

In those days, it can be observed that economic perspective in Islam was not applied to Islamic institutions such as Baitul-Mal, Zakat and Waqf. It is understandable the bureaucratic establishment of those institutions was still at a formative stage and thus in reality, those institutions had not yet been able to exclusively associate with economic functions in the society. The institution of Zakat as the Islamic obligatory dues was more closely related to social and religious responsibilities. It focuses on the collection and the distribution of Zakat to the poor as a whole. This was merely regarded as a minimal function in terms of addressing financial difficulties in the Malay societies because it was not relevant to the economic improvement of the community especially with the debt repayment problem. As for Waqf, this involved the property 
and finance that only applied to religious institutions such as mosques, religious schools or madrasah and cemeteries. ${ }^{55}$

In a broader context, it is important to form a constructive view in order to examine the extent of the failures and successes of the Malays in economic achievements. In those days, the Malays of both upper and lower classes were still finding the formula in order to adapt themselves with the new economic orientation of capitalism and commercialism. The Malays in general needed the knowledge and expertise to manage their economic affairs. They had to give continuous commitment to pursue economic progress. However, it was evident that even the Malay aristocrats did not have the expertise and were still dependent on the joint ventures with the Chinese in managing their money matters even though they had been directly involved in commercial economy. It is a common knowledge that the Chinese progress and dynamism in economic affairs were manifested by the fact that they not only formed joint ventures but also competed with the European. ${ }^{56}$ According to Leo Suriadinata who has extensively conducted the studies on the Chinese in Southeast Asia, the main factor for the success of the immigrant Chinese here was their knowledge in handling money in business. ${ }^{57}$ Certainly, there is reservation if this view is to be applied to the Malays. However, the question here is that although the Malays realised that and intended to become involved in commercial activities, they were still more likely exposed to the risk of failure.

Thus, in order to achieve economic progress, the Malays had to engage in activities that could generate income but were less exposed to risks. Fortunately, the younger generations were now exposed to other sources of income as a result of the introduction of modern educational system and the establishment of civil services which generated salary and allowance on continuous and permanent basis. This new opportunity certainly brought a major impact on the peasant community to acquire the potentials for vertical economic mobilization in the colonial period. It led to the emergence of the middle class among the rakyat even if it was still at an elementary stage and was a gradual process. Among those who were classified into the middle class in those days were teachers, civil servants, journalists and traders. ${ }^{.8}$

In principle, the elementary economic mobilization to middle class was regarded as having an impact on the transformation of the peasant communities in both social and economic perspectives in the early twentieth century. The emergence of the middle class certainly reflected the progressive and dynamic dimension in the society especially the peasant communities in the villages. A higher status for an individual could be accomplished through increasing the level of education. With higher qualification, an individual could attain higher position because 
the new system and orientation recognised the position and status based on achievements rather than inheritance or family background. In reality, it was still quite difficult for the individuals from peasantry backgrounds to attain high status. This is because even based on educational achievement, the Malay aristocrats still had the advantages over the rakyat to hold the prestigious posts such as magistrates, district officers and assistant district officers. It can also be observed that there were marginal participations of the Malays in professional occupations such as lawyers, accountants and medical doctors. Most of the Malays who were associated with those occupations were the mixed blood individuals of the Muslim immigrant descendants especially the Arab Saiyids. For instance, the legal profession was referred to Syed Umar Al-Sagoff \& Co. and Syed Mohamed Al-Habshee who became the advocates in Johor. They also had the license to be assistant property evaluators in Johor Bahru. ${ }^{59}$

\section{Conclusion}

In general, it can be concluded that in the late nineteenth and early twentieth centuries, the Malay society in Malaya had undergone the process of economic transition rather than change. In this context, the term 'transition' here is applied to the Malays as a whole because the degree of change in the economic aspect and orientation was merely a gradual process of transformation rather than a drastic one. During this period, the economic change is always referred to the transformation from traditional to modern orientation. This phenomenon is manifested by the changes from subsistence to commercialism which was enhanced by the economic system based on capitalism, the adoption of the concept and practice of specialization and the use of intensive labour in economic productivity.

The process of economic transformation in the Malay society as a whole was mostly dependent on the availability of financial sources derived from subsidy and agricultural credit facilities. The Malay peasants had to depend on government funds, or the capital injection from the Malay chiefs and immigrant mercantile communities who had long been accustomed to money economy. Under this circumstance, it is understandable that they highly needed government funding especially in padi cultivation which was proven to be less profitable compared to other commercial crops such as rubber pepper, gambier and tapioca. In fact, padi cultivation was more risky compared to other agricultural activities because of its nature of highly depending on excessive irrigation and continuous water supplies throughout the process of cultivation. 
The most practical means for the Malays to benefit from the economic change in the nineteenth and early twentieth centuries was the adoption of private land ownership which was achieved through opening jungle land for agricultural activities. However, the economic achievement of the Malays was only restricted to small holdings due to the small size of land in possession. Another means of change was derived from the conversion of non-monetary labour or forced labour to waged labour under the capitalist orientation.

\section{Notes}

1 See I. A. Mills, British Malaya 1824-67, Kuala Lumpur: MBRAS Monograph, Oxford University Press, 1960; R. Emerson, Malaysia: A Study in Direct and Indirect Rule, Kuala Lumpur: University of Malaya Press, 1964; E. Thio, British Policy in the Malay Peninsula: 1880-1910 (Volume I: The Southem and Contral States), Singapore: Oxford University Press, 1969; Khoo Kay Kim, The Westem Malay States: The Effects of Commercial Development on Malay Politics, 1850-1873, Kuala Lumpur: Oxford University Press, 1972; I. M. Gullick, Rulers and Residents: Influence and Potwer in the Malay States 1870 1920, Singapore: Oxford University Press, 1992.

2 Lim Teck Ghee, Peasants and Their Agricultural Economy in Colonial Malaya 1874-1941, Kuala Lumpur: Oxford University Press, 1977, pp. 12-16.

3 For further detail on slavery in the traditional Malay society in the nineteenth century, see the Seventh chapter of I. M. Gullick, Indigenous Political Systems of Western Malaya, London: The Athlone Press, 1958.

* See the provision of land in the Melaka Digest in Liaw Yock Fang, Undang-Undang Melaka, The Laws of Melaka, Leiden, The Hague-Martinus Nijhoff: Bibliotheca Indonesica, Koninklijk Instituut voor Taal-, Land- en Volkenkunde (Royal Institute of Linguistics and A nthropology), 13, 1976, pp. 110-11.

5 Paul H. Kratoska, 'Land Law and Land Tenure in British Melaka' in K. S. Sandhu and Paul Wheatley, (eds) Melaka: The Transformation of Malay Capital C. 1400-1980, Vol. 1, Kuala Lumpur: Oxford University Press, 1982, pp. 500-20.

" "Trip to the Johore River", Singupore Chronicle, August 1826, Library of the National University of Singapore.

P. J. Begbie, The Malay Peninsula, Madras, 1834, pp. 288-9.

* C. B. Buckley, An Anecdotal History of Old Times in Singapore 1819-1867, (first edition, 1902) second edition, Kuala Lumpur: University of Malaya Press, 1965, pp. 402-5, 483.

- C. A. Trocki, Prince of Pirates: The Tenenggongs and The Development of Johor and Singapore 1784-1885, Singapore: Singapore University Press, 1979, pp. 26-117.

10 Ahmad Nazri Abdullah, Melayu Dan Tanuh: Tumpunn Khnsus Kepuda Tanh Simpanan Melayu, Kuala Lumpur: Media Intelek Sdn. Bhd., 1985, pp. 1-13.

11 Paul H. Kratoska, 'Land Law and Land Tenure in British Melaka', pp. 500-20. 
12 The discussion on the geographical factors which determine the pattern of settlement of the population during pre-colonial period can be found in the writing of Zaharah bt Mahmud, 'The Traditional Malay Ecumene of The Peninsula', in P. K. Voon and T. S. Bahrin (eds.), The Viero from Within: Geographical Essays on Malaysia and Southeast Asia, Kuala Lumpur, Department of Geography, University of Malaya, 1992, p. 309.

13. Isabella Bird, The Golden Chersonese and The Way Thither, (first edition, London: 1883) Second edition, Kuala Lumpur: Oxford University Press, 1967; Florence Caddy, To Sian and Malaya in the Duke of Sutherland's Yacht, (first edition London: Sans Pent, 1889), second edition with a biographical note on the author by J. M. Gullick, London \& New York: Oxford University Press, 1992), pp. 232-79, p. 137.

14 J.M. Gullick, Malay Society in The Late Nineteenth Century: The Beginnings of Change, p. 194.

15 Ronald D. Hill, 'The History of Rice Cultivation in Melaka' in Sandhu and Wheatley, (eds) Melaka, pp. 535-67, pp. 538-9.

16 Sharom Ahmad, Tradition and Change in A Malay State: A Study of the Economic and Political Development of Kedah 1878-1923, Kuala Lumpur: Malaysian Branch of The Royal Asiatic Society (MBRAS) Monograph no. 12,1984 , pp. $17-45$, p. 17.

17 Paul H. Kratoska, 'Land Law and Land Tenure in British Melaka', pp. 513-20.

18 Mohd. Fadzil Othman, Kisah Pelayaran Mohammed Ibrahim Munsyi, Kuala Lumpur: Dewan Bahasa dan Pustaka, 1980, pp. 35, 135. Hereafter known as Kisah Pelayaran Mohamned Ibrahim Munsyi.

19 Donald M. Nonini, British Colonial Rule and the Resistance of the Malay Peasantry, 1900-1957, Monograph Series 38, Yale: Yale University Press, 1991, pp. 21-76, p. 18.

20 A. E. Coope, 'The Kangchu System in Johore', in R.O. Winstedt, A History of Johor 1365-1895 A. D., Kuala Lumpur: Art Printing Works, 1979, pp. 163-79.

21 Sharom Ahmad, Tradition and Clange in A Malay State, pp. 19-27.

22 Trocki, Prince of Pirates, pp. 153-77.

23 Historically, Mercantilism is the doctrine, developed in the West after the decline of feudalism, that a nation's economy could be strengthened by governmental protection of home industries, by increased foreign exports, and by accumulating gold and silver

24 John H. Drabble, An Economic History of Malaysia, c. 1800-1990: The Transition to Econonic Grozoth, London: Macmillan Press Ltd., 2000, pp. 9-26, pp. 9-20.

25 Gullick, Malay Society iu The Late Ninetenth Century, pp. 184-5.

26 The historical development of the abolition of slavery in Malay is discussed by Moshe Yegar, 'The Abolition of Servitude in British Malaya: An Historical Analysis', Isnael Yearbook on Human Rights, Vol. 5, Tel Aviv: 1975, pp. 204-215.

27 Straits Daily Times, 6 May, 1879; See also Titos Heslop Hitl, "Reports on Johor", Singapore: 1879, p. 2. This pamphlet is available at The Johor 
Branch of the National Archive of Malaysia, Johor Baharu, hereafter referred as the Johor Archive.

28 E. Sadka, The Protected Malay States 1874-1895, Kuala Lumpur: University of Malaya Press, 1968 , p. 325.

29 The detail on the introduction of land law during the British colonial period in the late nineteenth century can be found in W. E. Maxwell, Memorandum on the Introduction of Land Code in the Natice States in the Malaya Peninsula, Singapore,: 1894; Sadka, The Protected Malay States, pp. 341-5 and Ahmad Nazri Abdullah, Melayu Dan Tanah, pp. 21-34.

30. See the samples of the revenue farms in Johor in Buku Daftar Surat Jualbeli, Pajak Gadai dan Hutang 1284-1301H/1867-1884M, the Johor Archive.

31 Various samples of 'Surat Sungai' and other documents relating to the Kangchu System can be found in C. A. Trocki, 'The Johor' Archives and the Kangchu System', JMBRAS, Vol. 48, pt. I, 1975, pp. 13-50.

32 Surat-surat tauliah Penghulu dalam daerah Muar 1873-1874, //MB 3 , The Johor Archive.

33 Mohd. Hj. Elias, Tawarikh Dafu Bentara Luar, edited by Amin Sweeney, Berkeley: University of California Press, 1980, pp. 6-8. Hereafter known as Tawarikh Datu Bentara Luar.

34 See the provision of Section 9 of The Johore Land Enactment of 1910 the Johor Archive The land tax charge in the Johor Land Enactment was adopted from the previous provisions of the land enactments in the Federated Malay States.

35 P. T. Bauer and B. S. Yamey, The Economics of Under-Developed Conntries, Cambridge: Cambridge University Press, 1965, p. 107.

36. Further detail on the problem of land alienation among the Malays can be found in Ahmad Nazri Abdullah, Melayn Dint Tanal, pp. 184-210.

Nonini, British Colonial Rule, p. 24.

Khoo Kay Kim, Malay Society, pp. 96-97.

Sharom Ahmad, Tradition and Change in A Malay State, pp. 19-45.

See all the concessions related to revenue farms in padi cultivation in Surat menyurat Sultan Abdul Hamid No. 2, 1304-1312'H (1884-1895 CE.), Arkib Negara Malaysia Cawangan Kedah, Alor Merah, Kedah, Hereafter known as 'The Kedah Archive.

4 Lim Teck Ghee, Peasants and Their Agricultural Economy, pp. 39-49.

42. Hill, 'The History of Rice Cultivation in Melaka', pp. 550-55.

43 William R. Roff, Kerjasama Dan Koperasi Di Semenanjung 1910-1941: Petikan dari bahan-baltan terbitan sezaman, Kuala Lumpur: Penerbit Universiti Malaya, 1984, p. 1.

44 See the origins of the Krian irrigation scheme for padi cultivation in Lim Teck Ghee, Origins of A Colonial Econony: Land and Agriculture in Perak 1874-1897, Pulau Pinang: Universiti Sains Malaysia, 1976, pp. 56-61.

45 Roff, Kerjasama Dan Koperasi Di Semenanjung, pp. 2-8.

46 Extract from the Report and Proceedings of the Committee appointed by the Chief Secretary, Federated Malay States, to Consider why the System of Small Loans to Native Agriculturalists had Failed in Perak, July 1911. 
Kuala Lumpur: Government Printing Office, 1912, National Archive of Malaysia hereafter known as Malaysian Archive.

47 Agricultural Loan Fund Rules, 24 November 1911, Kuala Lumpur: Government Printing Office, 1911, Malaysian Archive.

48 See the discussion on the origins of the Malay Reserved Land Enactment of 1913 in Ahmad Nazri Abdullah, Melayu Dan Tanah, pp. 51-73.

49 Report on the Advisability of Establishing Agricultural Banks or Cooperative Societies in the Federated Malay States, General Committee of F.M.S. Chamber of Commerce, Kuala Lumpur: 1918, Malaysian Archive, p. 12.

50 Utusan Melayu, 4 Feb., 1908, in Roff, Kerjasama Dan Koperasi Di Semenanjung, p. 22.

51 Nonini, British Colonial Rule, pp. 66-69.

52 Report on the Advisability of Establishing Agricultural Banks or Cooperative Societies in the Federated Malay States, General Committee of F.M.S. Chamber of Commerce, Kuala Lumpur: 1918, Malaysian Archive, p. 12.

53 Articles extracted from the contemporary Malay newspapers and magazines in this period can be found in the transliteration versions of Roff, Kerjasama Dan Koperasi Di Semenanjung, pp. 143-91.

54 A. Cavendish, Co-operation as Subject for Study in Malaya, Pinang Gazette Press, 1922, Penang Branch of the National Archive of Malaysia hereafter known as Penang Archive.

55 Moshe Yegar, Islam and Islamic Institution in British Malaya, Jerusalem: Hebrew University Press, 1979, pp. 205-233; M. B. Hooker, Islantic Law in South-East Asia, Singapore: Oxford University Press, 1984, pp. 131-63; M. B. Hooker, Ed., Islam in Southeast Asia, Second impression, Leiden: E.J. Bril, 1988, pp. 160-182, pp. 205-22.

56 For the detail on the economic progress of the Chinese in Malaya and Southeast Asia in general, see Rajeswary Ampalavanar Brown, Capital and Entrepreneursliti in Southenst Asia, Hampshire and London: MACMILLAN PRESS LTD., and New York: ST. MARTIN'S PRESS, INC., 1994, pp. 77172.

57 Leo Suryadinata, Understanding the Ethnic Chinese in Southeast Asia, Singapore, Institute of Southeast Asian Studies (ISEAS), 2007, pp. $29-49$.

58 A. C. Milner, The Invention of Politics in Colonial Malaya: Contesting Nationalism and the Expansion of the Public Sphere, Cambridge: Cambridge University Press, 1995, pp. 89-113.

$59 \quad$ Singapore and Straits Directory (SSD) 1910, p. 40 and SSD, 1912, p. 48. 